\title{
Seasonal evolution of supraglacial lakes on a floating ice tongue, Petermann Glacier, Greenland
}

\author{
Grant J. MACDONALD, ${ }^{1}$ Alison F. BANWELL, ${ }^{2}$ Douglas R. MacAYEAL ${ }^{1}$ \\ ${ }^{1}$ Department of the Geophysical Sciences, University of Chicago, Chicago, IL 60637, USA. \\ E-mail: gjmacdonald@uchicago.edu \\ ${ }^{2}$ Scott Polar Research Institute, University of Cambridge, Lensfield Road, Cambridge, CB2 1ER, UK
}

\begin{abstract}
Supraglacial lakes are known to trigger Antarctic ice-shelf instability and break-up. However, to date, no study has focused on lakes on Greenland's floating termini. Here, we apply lake boundary/area and depth algorithms to Landsat 8 imagery to analyse the inter- and intraseasonal evolution of supraglacial lakes across Petermann Glacier's $\left(81^{\circ} \mathrm{N}\right)$ floating tongue from 2014 to 2016 , while also comparing these lakes to those on the grounded ice. Lakes start to fill in June and quickly peak in total number, volume and area in late June/early July in response to increases in air temperatures. However, through July and August, total lake number, volume and area all decline, despite sustained high temperatures. These observations may be explained by the transportation of meltwater into the ocean by a river, and by lake drainage events on the floating tongue. Further, as mean lake depth remains relatively constant during this time, we suggest that a large proportion of the lakes that drain, do so completely, likely by rapid hydrofracture. The mean areas of lakes on the tongue are only $\sim 20 \%$ of those on the grounded ice and exhibit lower variability in maximum and mean depth, differences likely attributable to the contrasting formation processes of lakes in each environment.
\end{abstract}

KEYWORDS: Arctic glaciology, glacier hydrology, ice-shelf break-up, ice shelves

\section{INTRODUCTION}

Supraglacial lakes (SGLs) are known to affect the stability of ice shelves, which have an important buttressing effect on outlet glaciers around ice sheets (e.g. Scambos and others, 2004; Dupont and Alley, 2005; De Rydt and others, 2015). Therefore, SGLs on ice shelves are likely to play an important role in the response of ice sheets to climate change, with recent studies suggesting that surface meltwater could become a primary factor in the future demise of Antarctica's ice shelves (e.g. DeConto and Pollard, 2016).

Around the north coast of the GrlS, numerous outlet glaciers terminate in narrow floating ice shelves, situated in confined fjords; features that we call 'tongues' in this study. In comparison, Antarctic ice shelves are more typically present in wider embayments. However, as the floating glacier ice in both environments is commonly constrained by embayment walls, both are typically subject to stress at their lateral margins and exhibit shear profiles in their seaward velocity. Although the magnitudes of these shear stresses will differ, floating ice shelves and tongues are considered similar in their form and environmental setting.

Although recent research has shown that numerous Antarctic ice shelves experience surface melting sufficient to enable widespread surface stream and lake formation (Langley and others, 2016; Lenaerts and others, 2016; Bell and others, 2017; Kingslake and others, 2017), to our knowledge, no studies of SGLs on the floating tongues around the Greenland ice sheet (GrlS) exist. Therefore, our prior knowledge of the evolution and effects of SGLs on the stability of the floating glacier ice around Greenland comes from previous studies of SGLs on Antarctic ice shelves.

Around the Antarctic ice sheet (AIS), SGLs on ice shelves have been shown to promote ice-shelf instability and potential break-up in three ways. SGLs can: (i) fill and propagate fractures downwards through the ice (i.e. 'hydrofracture', Weertman, 1973; van der Veen, 1998, 2007; Alley and others, 2005), enabling them to drain rapidly (Scambos and others, 2000, 2003; Gilbert and Domack, 2003; Banwell and others, 2013); (ii) act as time-dependent loads, which can cause a flexural response of the ice shelf, thereby weakening the ice shelf (MacAyeal and Sergienko, 2013; Banwell and MacAyeal, 2015); and (iii) have a positive feedback effect on surface melt rates through enhanced lake-bottom ablation due to the lower albedo of water compared with the surrounding ice/snow (Tedesco and others, 2012).

While SGLs on grounded ice form in depressions that reflect bedrock topography and ice flow conditions (Echelmeyer and others, 1991; Sergienko, 2013), SGLs on floating ice shelves develop within surface topographic undulations that form in response to a variety of processes, including: (i) basal crevassing (McGrath and others, 2012) and channelling (Le Brocq and others, 2013); (ii) grounding-line flexure (e.g. Walker and others, 2013); and (iii) incomplete flexural rebound from previous lake drainage events that often result in the formation of 'dolines' (Glasser and Scambos, 2008; Banwell and MacAyeal, 2015). This means that in contrast to SGLs on grounded ice that remain in a fixed interannual location (Thomsen and others, 1988; Selmes and others, 2011), SGLs on floating ice usually advect with ice flow (Banwell and others, 2014; Langley and others, 2016). Alternatively, SGLs on ice shelves may form in 'pressure rolls' associated with compressive stress at the boundaries between floating ice and land. Consequently, SGLs in these pressure rolls will migrate at a speed and direction that differs from ice flow (LaBarbera and MacAyeal, 2011). In addition to the presence of a surface topographic depression, lake formation on floating or grounded ice requires a surface of bare ice or firn that is 
sufficiently impermeable to enable water to pond (Scambos and others, 2000; Banwell and others, 2012; Lenaerts and others, 2016; Bevan and others, 2017).

Although various studies have suggested that SGLs on Antarctic ice shelves may have drained rapidly by hydrofracture, such as on the Larsen B Ice Shelf (Scambos and others, 2003; Glasser and Scambos, 2008; Banwell and others, 2013), no direct observations exist. The quickest observed SGL drainage event on an ice shelf took 5 days (Langley and others, 2016), however, the precision of this drainage time is likely to be limited by the return-time of satellite imagery. Based on the physics of the hydrofracture mechanism (e.g. Weertman, 1973; van der Veen, 1998, 2007; Alley and others, 2005), lake drainage through this process is likely to occur over the order of a few hours on floating ice (Banwell and MacAyeal, 2015), comparable with the time that this process has been observed to take on the grounded ice of the GrIS (e.g. Das and others, 2008; Tedesco and others, 2013; Williamson and others, 2018). Alternatively, SGLs on Antarctic ice shelves have been observed to drain more slowly by overspilling their basins. And/or, they may either partially drain, or not drain at all, and instead refreeze (Langley and others, 2016) and/or become covered in snow (Koenig and others, 2015; Lenaerts and others, 2016).

For both the AIS and GrIS, the loss of the buttressing forces provided by floating ice shelves and tongues has been observed and modelled to significantly increase upstream outlet glacier flow speeds. For example, the collapse of Antarctica's Larsen B Ice Shelf in 2002 caused a multiannual sixfold increase in speed, grounding-line retreat and thinning of tributary glaciers feeding it (Rignot and others, 2004; Scambos and others, 2004; Rott and others, 2011; De Rydt and others, 2015; Wuite and others, 2015). Similarly, the loss of $95 \%$ of north Greenland's Zachariae Isstrom's ice shelf between 2002 and 2014 caused the glacier's flow rate to almost double (Mouginot and others, 2015).

Given the importance of the buttressing force of ice shelves against inland ice, and the clear link between ice shelf SGLs and stability that has already been established in Antarctica, this study aims to present the first analysis of SGLs on one of Greenland's floating tongues.

Focusing on Petermann Glacier, northwest Greenland, our first objective is to analyse the inter- and intraseasonal evolution in the overall pattern of lakes on its floating ice tongue over three consecutive melt seasons, 2014, 2015 and 2016. Our second objective is to focus more specifically on the inter- and intraseasonal evolution of two individual SGLs that repeatedly fill and drain during the three melt seasons. And finally, to help determine the extent to which our extensive knowledge of SGLs on the GrIS's grounded ice can be applied to SGLs on floating tongues, our third objective is to compare the characteristics of a subset of SGLs on the floating tongue to SGLs on the grounded ice of Petermann Glacier during June 2014.

\section{STUDY SITE}

Petermann Glacier (Fig. 1), northwest Greenland $\left(81^{\circ} \mathrm{N}\right)$, drains $\sim 4 \%$ of the ice sheet northwards into Petermann Fjord (Münchow and others, 2014). It terminates in a floating tongue that had an area of $\sim 1000 \mathrm{~km}^{2}$ in 2016 . As is typical of floating tongues and ice shelves, it has a low surface gradient; the elevation change is only $\sim 40 \mathrm{~m}$ over a distance of $\sim 40 \mathrm{~km}$ from the ice front to the grounding line. Ice thickness varies

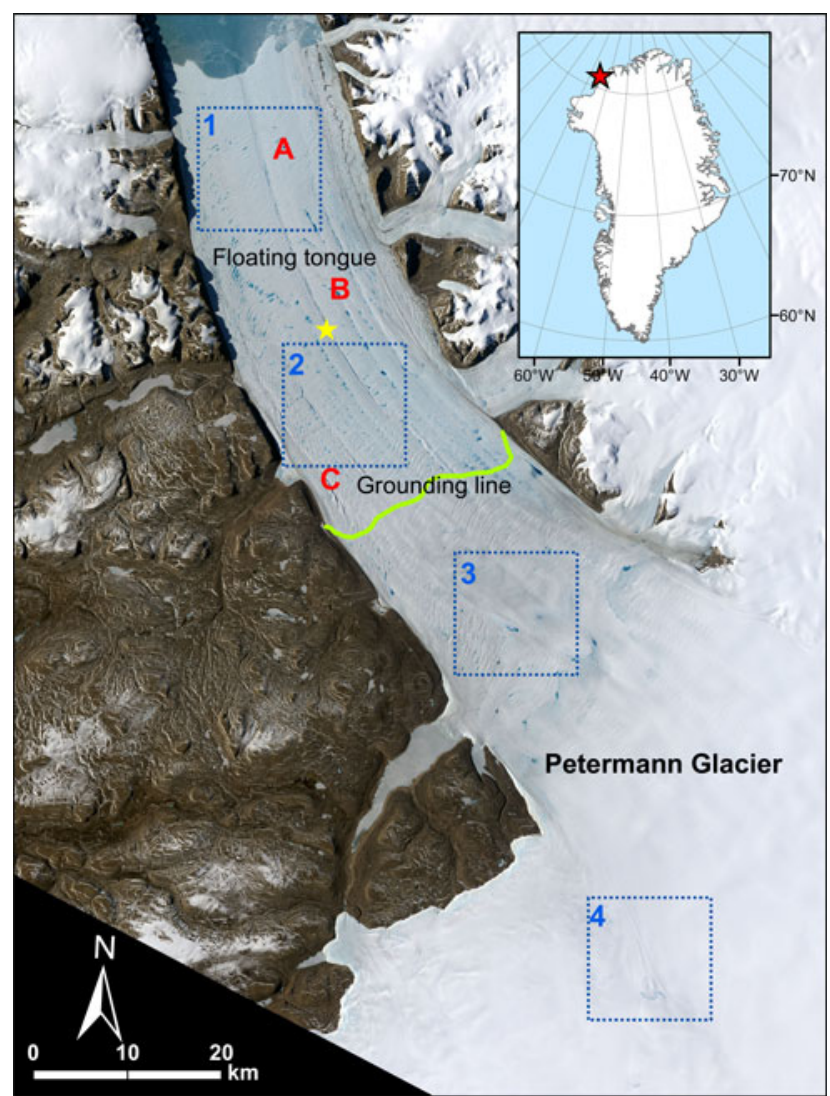

Fig. 1. The study site, Petermann Glacier, northwest Greenland, shown in a pan-sharpened true colour Landsat $8 \mathrm{OLI}$ image, dated 18 June 2016. The approximate grounding line position (following Rignot, 1998) is shown by the green line. The letters A, B and C indicate the locations of lakes shown in Figures 6 and 7, and the numbers 1-4 indicate the location of the subsampled areas used to compare SGLs on the floating and grounded ice in Figures 8 and 9. The yellow star indicates the location of the $\sim 5.5 \mathrm{~km}^{2}$ pixel from HIRHAM5's output used to represent daily mean surface temperature.

across the tongue but ranges from $\sim 600 \mathrm{~m}$ by the grounding line to $<100 \mathrm{~m}$ close to the terminus (Münchow and others, 2014). It is one of only seven glaciers in Greenland with a permanently floating tongue, all of which are located on the north coast (Moon and others, 2012).

The glacier lost $\sim 40 \%$ of its tongue in two massive calving events in 2010 and 2012, and its terminus is now at its most retreated position since records began (Nick and others, 2012; Münchow and others, 2014). These large calving events, however, did not cause a significant change in the velocity or thickness of the glacier (Nick and others, 2012) and research suggests that the grounded glacier is currently dynamically stable. Its grounding line is at $\sim 600 \mathrm{~m}$ below sea level on a forward slope, and the bed remains below sea level up to $\sim 80 \mathrm{~km}$ inland of the grounding line (Rignot, 1998; Bamber and others, 2013). Although the position of the grounding line has varied by an average of $470 \mathrm{~m}$ between 1992 and 2011 (with a maximum range of $7 \mathrm{~km}$ ), it experienced no systematic retreat or advance (Hogg and others, 2016). However, this does not preclude the potential for future changes in the glacier's velocity and mass balance in response to tongue break-up events (Nick and others, 2012; Hogg and others, 2016).

For the GrlS as a whole, the average daily melt during the summers of the study period 2014-16 was largely 
unremarkable compared with the preceding decade but continued the overall trend of increased melting (Tedesco and others, 2014, 2015, 2016). Additionally, data from an icesheet wide network of weather stations (PROMICE) suggests that net ablation, especially in northern regions, has been larger in recent years (2008-15) than during any period in the previous $\sim 150$ years (van As and others, 2016).

\section{DATA AND METHODS}

\section{Satellite image acquisition and processing}

All Landsat 8 Operational Land Imager (OLI) images of Petermann's floating tongue that were either completely or partially cloud-free for the boreal summers (i.e. JuneAugust) of 2014, 2015 and 2016 were downloaded from the EarthExplorer website (Tables S1 and S2).

OLI imagery was partly chosen for its high spatial resolution $(30 \mathrm{~m})$, compared with, for example, Moderate Resolution Imaging Spectroradiometer (MODIS) imagery; the resolution $(250 \mathrm{~m})$ of which precludes such accurate lake identification and volume analysis. OLI imagery also does not have the missing scanlines of Landsat 7 Enhanced Thematic Mapper Plus (ETM+), and therefore, we choose to study the three summers succeeding the launch of Landsat 8. Compared with ETM+, OLI also has enhanced radiometric resolution ( 12 bit compared with 8 bit), and features narrower multispectral and panchromatic bands, allowing for improved lake-identification and lake-depth estimation. Additionally, OLI has a higher temporal acquisition rate than ETM+ and although it has a 16-day revisit time, the overlap between orbits means that images of the study site were sometimes acquired for consecutive days.

Once acquired, images were cropped to the area of interest in ArcMap ${ }^{\mathrm{TM}}$. Subsequently, the up-glacier boundary of the floating tongue was defined, based on the position of the grounding line estimated by Rignot (1998). As mentioned in the section above, although the grounding line position has varied over the last three decades, it has not systematically retreated or advanced, and thus this grounding line position is considered the best estimate for this study.

\section{Seasonal evolution of SGLs from 2014 to 2016 (objective i)}

To conduct analysis of the inter- and intraseasonal evolution of SGLs (2014-16), only images that were completely cloud-free over the tongue (15 images in 2014, 18 in 2015 and 24 in 2016) were used (Table S1). Following processing (section 'Satellite image acquisition and processing'), a mask of SGL boundaries in each image was produced in MATLAB ${ }^{\mathrm{TM}}$ using a lake boundary/area algorithm, following the method of Banwell and others (2014), which is based on the algorithm developed by Box and Ski (2007) (see the Supplementary Information for further details). From the masks, total lake number (TLN) and total lake area (TLA) were calculated for each image in each of the three melt seasons. Next, following the method of Sneed and Hamilton (2007) and Banwell and others (2014), but adapted for OLI instead of ETM+ (Pope and others, 2016), a lake-depth algorithm was applied to calculate the water depth of all pixels previously identified as being part of a lake (see the Supplementary Information for further details). Using these results, total lake volume (TLV) and mean lake depth (MLD) for each image was calculated.
Next, to analyse the inter- and intraseasonal evolution of TLN, TLV, TLA and MLD in response to air temperature and thus surface melt conditions on the floating tongue, these four calculated statistics were compared with both the surface air temperature and surface runoff products from the Danish Meteorological Institute's (DMI) HIRHAM5 regional climate model for all years. These data were sourced from HIRHAM5's daily meteorological re-analysis product for 2014 (documented in Langen and others, 2017) and the operational product for 2015 and 2016 (as the reanalysis product for 2015 and 2016 was not yet available at the time of our study). A single $\sim 5.5 \mathrm{~km}^{2}$ cell, located mid-way up the tongue (at $60.6^{\circ} \mathrm{W}, 80.7^{\circ} \mathrm{N}$, Fig. 1), from the DMI's model output, was used to represent mean daily air temperatures of the tongue throughout the study period. This was deemed acceptable as the magnitudes and seasonal trends in runoff (and therefore air temperatures) across the relatively flat tongue do not show significant variation (Fig. 2). Additionally, for each year, HIRHAM5's surface runoff product was used to analyse the mean daily surface runoff across the tongue for the periods 1-15 June, 16-30 June, 1-15 July, 16-31 July, 1-15 August and 16-31 August. There is no observational weather data available for the region during the study period with which to facilitate an assessment of HIRHAM5's validity in the study area. However, HIRHAM5's overall performance has been validated against observations from the PROMICE network of automatic weather stations across the GrIS (Langen and others, 2015, 2017), and we regard this validation sufficient for the present study.

\section{Seasonal evolution of individual SGLs (2014-16) (objective ii)}

To analyse the inter- and intraseasonal evolution of individual lakes, with a specific focus on their filling and drainage patterns, two lakes that were observed to fill and drain from a sequence of high-temporal resolution imagery were chosen (Lakes A and B, locations indicated in Fig. 1). This analysis made use of images that were completely cloud-free over the tongue and also the images that were at least cloud-free at the sites of the specific lakes (15 images for Lake A, 33 for Lake B; Table S2). All selected images were cropped to only include Lake A or B, and lake volumes in each image were calculated using the lake boundary/area and depth algorithms. A lake was deemed to have drained 'rapidly' if $>90 \%$ of volume drained within $48 \mathrm{~h}$ (Selmes and others, 2011), or 'slowly' if drainage exceeded this time. Finally, to include examples of lakes that do not drain in our analysis, two cloud-free images of a group of lakes (location indicated by $\mathrm{C}$ in Fig. 1) that freeze-over and/or are buried by snow were analysed by manual visual interpretation.

\section{Comparison of SGLs on the floating tongue and grounded ice (objective iii)}

To compare SGLs on the floating tongue with those on the grounded ice, four equally-sized areas $\left(187 \mathrm{~km}^{2}\right)$ were selected, two of which are located on the tongue (Sites 1 and 2 in Fig. 1) and two on the grounded ice (Sites 3 and 4 in Fig. 1). An OLI image dated 30 June 2014 was used to analyse SGLs within Sites 2, 3 and 4, but as Site 1 did not fall within this image, an OLI image captured 3 days earlier (27 June 2014) was instead used for this site. These images 


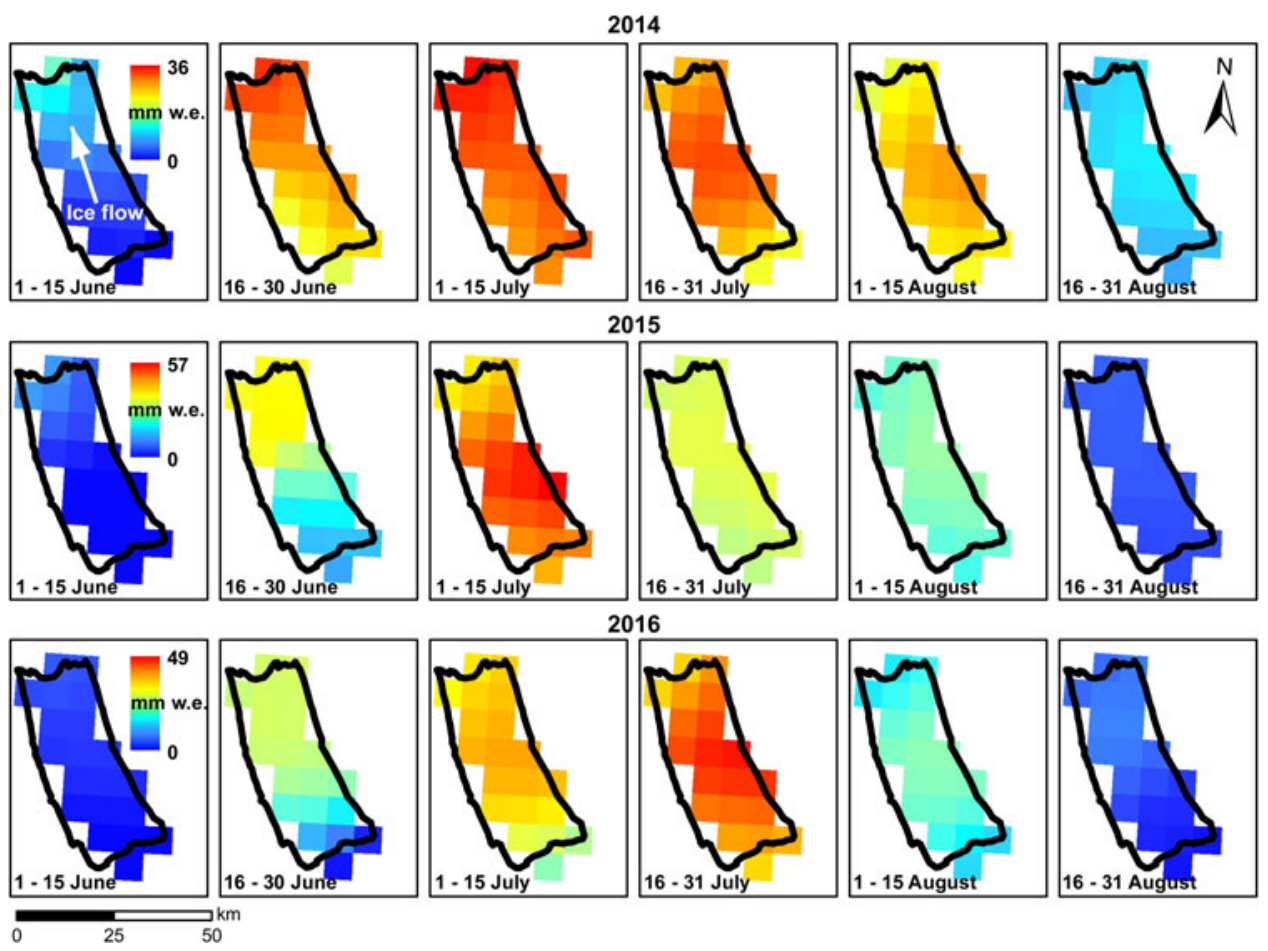

Fig. 2. Mean daily surface runoff ( $\mathrm{mm}$ w.e.) through the 2014, 2015 and 2016 melt seasons. Petermann's floating tongue is shown by the black outline. Plots within each year have the same colour bar scale.

from late June were chosen because it was then that SGLs were widespread on both the floating tongue and the upglacier grounded ice, and there was no single cloud-free image that included all four sites around this time.

The two images were cropped to each site's area of interest and the lake boundary/area and lake-depth algorithms were used to calculate the maximum and mean depths, and areas, for SGLs in each site. The results from the two floating tongue sites ( 1 and 2 ) and two grounded sites ( 3 and 4) were each combined into 'floating' and 'grounded' sets of results, respectively, and were quantitatively compared.

\section{RESULTS}

\section{Intra- and interseasonal evolution of meltwater features on the floating tongue (2014-16)}

In each of the three melt seasons studied, SGLs first start to develop on the tongue in early June, before rapidly increasing in total number, volume, area and density over the following days and weeks (Fig. 3). For example, in just 1 day (11-12 June 2016) TLN, TLA and TLV increase by $173 \%, 270 \%$ and $248 \%$, respectively (Fig. 3 and Fig. S1). Mean daily temperatures $>0{ }^{\circ} \mathrm{C}$ are also first recorded in the first half of June each year. Peak TLN, TLA and TLV are reached in late June or early July in each year, but these peaks do not always occur simultaneously. Following these times, TLN, TLA and TLV decline throughout the rest of the summer, though some fluctuations around this trend do occur. Conversely, air temperatures peak in July or August, and the longest continuous periods of daily mean temperatures $>0{ }^{\circ} \mathrm{C}$ occur in these months, while TLN, TLA and TLV decline (Fig. 3 and Fig. S1). In contrast to TLN, TLA and TLV, MLD does not decline through July and August. Instead, after rising through June/early-July, MLD then becomes relatively stable (1-1.5 m) until the end of the season (Fig. 3).
SGL development varies spatially across the tongue during each melt season (Fig. S2). SGLs evolve up-glacier in both 2015 and 2016 (unfortunately, there is insufficient imagery during 2014 to evaluate this phenomenon). For example, between 16 June and 4 July 2015 (Fig. S2), the areal extent of SGLs declines on the lower part of the tongue, but increases in the upper $\sim 18 \mathrm{~km}$, close to the grounding line. A similar pattern is observed between 18 June and 25 June 2016. In both cases, this pattern of SGL expansion close to the grounding line is concurrent with an overall decrease in TLN, and an overall increase in TLV and MLD across the whole tongue (Fig. 3) (TLA slightly increases over this period in 2015 but decreases in 2016; Fig. S1). In each year, higher runoff values spread up-glacier as runoff increases. The location of the highest runoff value in each period also moves closer to the grounding line through June and July (Fig. 2).

At the time of peak TLA (Fig. S1), the area of the tongue covered by SGLs in 2014, 2015 and 2016, is 2.5, 2.3 and $2.8 \%$, respectively. The warmest melt season out of the three studied is 2016 , with a mean temperature of $0.65{ }^{\circ} \mathrm{C}$, and the coldest melt season is 2014 , with a mean temperature of $-0.06{ }^{\circ} \mathrm{C}$ (Fig. 3). Not surprisingly, 2016 also has the greatest number of days (69) with a mean temperature $>0{ }^{\circ} \mathrm{C}$ and the earliest day (7 June) with a mean temperature $>0{ }^{\circ} \mathrm{C}$. In contrast, 2014 has the smallest number of days (41) with a mean temperature $>0{ }^{\circ} \mathrm{C}$ and the latest day (14 June) with a mean temperature $>0{ }^{\circ} \mathrm{C}$. Further, 2016 records the highest TLN (1053 lakes) and TLA $\left(22.62 \mathrm{~km}^{3}\right)$ and earliest peak $\operatorname{TLV}\left(24.22 \times 10^{6} \mathrm{~m}^{3}\right)$. However, although 2014 records the lowest mean temperature, it has the highest peak TLV $\left(28.24 \times 10^{6} \mathrm{~m}^{3}\right.$, which occurs 9 days later than in 2016).

While the pattern of lake distribution across the tongue appears broadly similar in each year, there are small interannual differences in SGL locations due to ice flow (Fig. 4). During our study period, SGLs migrate down-glacier with ice flow at $\sim 1.2 \mathrm{~km} \mathrm{a}^{-1}$, which is comparable with the 


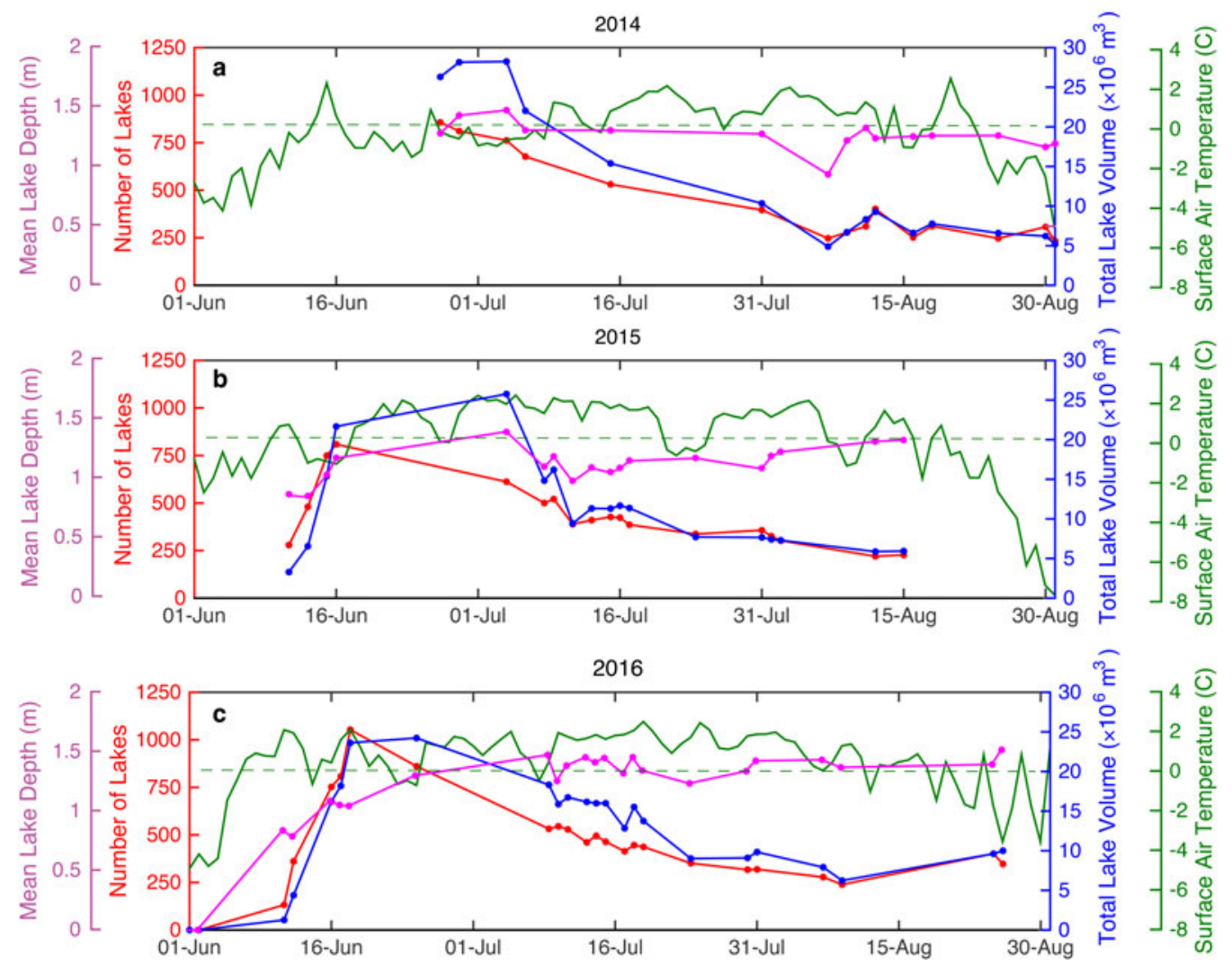

Fig. 3. Total lake number (TLN, red), total lake volume (TLV, blue), mean lake depth (MLD, purple) and daily mean surface air temperature (green) on Petermann's floating tongue in (a) 2014, (b) 2015 and (c) 2016.

velocity observations made by Nick and others (2012) (1.1$1.4 \mathrm{~km} \mathrm{a}^{-1}$ ).

We also note that in each melt season, a supraglacial river forms along the centre-line of the tongue and terminates at the ice front (Fig. 5), which is likely the same river identified in 2014 by Bell and others (2017). The river is visible in imagery between 27 June and 18 August 2014, 11 June and 14 August 2015, and 11 June and 9 August 2016. Each year, it reoccupies the same central channel that was observed by Münchow and others (2014), identified as an area of low ice thickness. Each summer, the river begins its activity on the same date that SGLs are first identified (midlate June). On 15 July 2016, a meltwater plume is visible in the ocean where the river terminates at the ice front (Fig. 5d). In all three melt seasons, the river remains active until it empties in mid-late August.
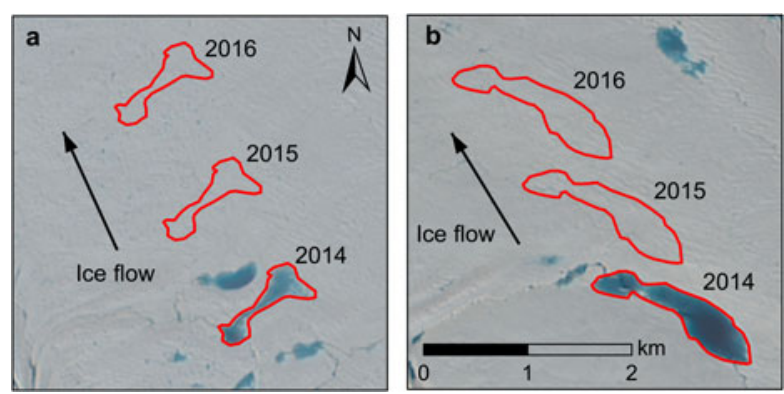

Fig. 4. The down-glacier interannual migrations of Lakes $A$ and $B$ between 2014 and 2016. (a) Lake A and (b) Lake B on 24 June 2014 and their positions on 16 June 2015 and 18 June 2016. The background of both panels is an OLI image dated 24 June 2014.

\section{Individual lake development and drainage on the floating tongue (2014-16)}

Following lake development in early June in all 3 years, SGLs generally expand in the area, coalesce with nearby lakes and then drain or become covered by snow or ice. We observe two instances of SGLs draining 'rapidly', both in 2014 (Figs 4 and $6 a$ and b). For example, between 24 and 25 June 2014, Lake A loses $96 \%$ of its $12.37 \times 10^{4} \mathrm{~m}^{3}$ volume and the remainder drains over the following day (Fig. 7a). The same lake, however, does not drain as rapidly in other years, taking $>4$ days to drain in 2015 and $>6$ days to drain in 2016 (Fig. 7a). Lake B also drains rapidly between 25 and 27 June 2014, when it loses 32\% of its volume after 1 day and $92 \%$ after 2 days (Fig. 7b). Like Lake A, Lake B also does not drain as rapidly in other years, taking $>18$ days to drain more than $90 \%$ of its volume in 2015 and $>7$ days in 2016 (Fig. 7b). Many SGLs, such as Lakes A and B in 2015 and 2016, drain slowly over several days to weeks by overflow into surface channels. Some of these SGLs drain fully and others only partially. Finally, many other SGLs do not drain at all, especially those close to the grounding line, such as those at location C (Fig. 1) and instead freeze-over and/or are buried by snowfall events in late August and early September (Fig. 6c).

\section{Comparison of lakes on floating ice with those on grounded ice}

Compared with SGLs on the floating tongue (Fig. 8), those on the grounded ice have a larger mean area of $0.140 \mathrm{~km}^{2}$ (Std dev.: $0.228 \mathrm{~km}^{2}$ ) and a larger median area of $0.025 \mathrm{~km}^{2}$ (Fig. 9). In contrast, SGLs on the floating tongue have a 

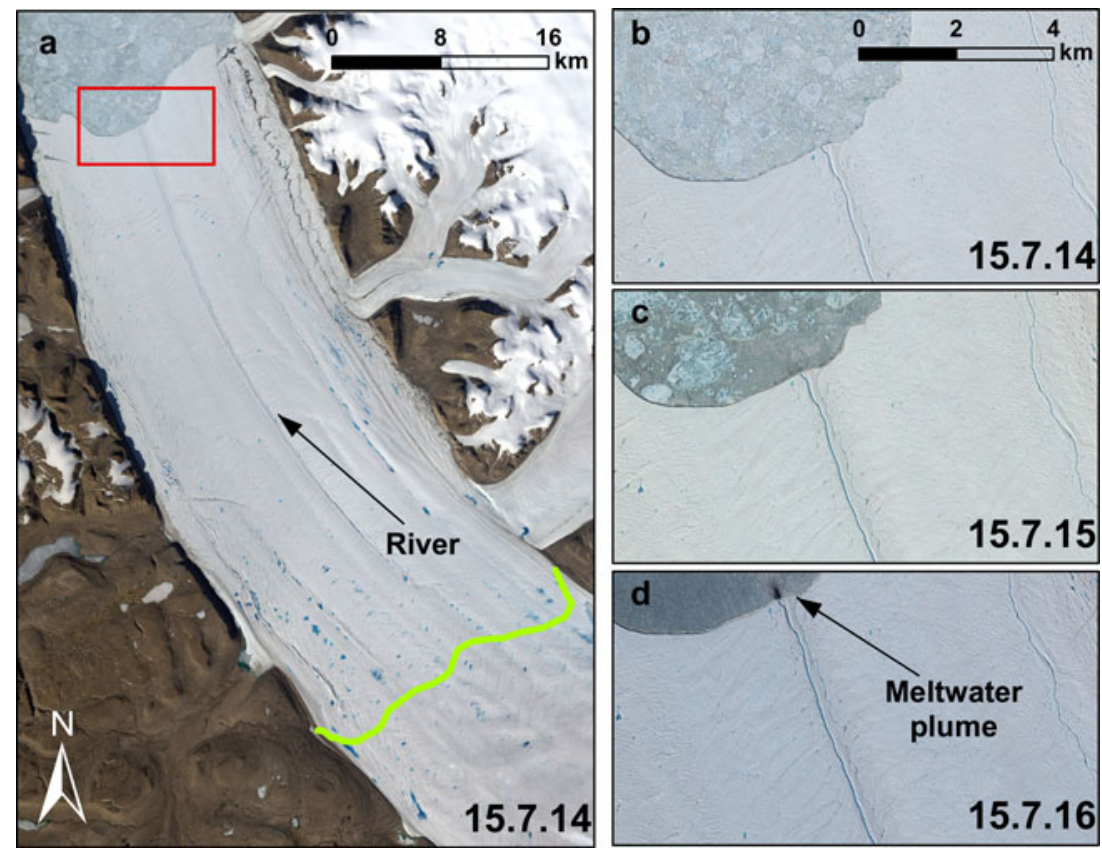

Fig. 5. The active river that forms annually down the centre-line of Petermann's floating tongue and terminates in the ocean. The whole tongue is shown on 15 July 2014, and just the terminus area is shown on 15 July in (b) 2014, (c) 2015 and (d) 2016 in pan-sharpened OLI images. The red box shows the location and extent of $(b-d)$ and the green line indicates the location of the grounding line (following Rignot, 1998). Note the visible meltwater plume in the ocean where the river terminates in 2016 (d).

mean area of $0.025 \mathrm{~km}^{2}$ (Std dev.: $0.033 \mathrm{~km}^{2}$ ) and a median area of $0.013 \mathrm{~km}^{2}(18 \%$ and $52 \%$ of the values for grounded SGLs, respectively). SGLs on the grounded ice also reach a much higher maximum area $\left(1.329 \mathrm{~km}^{2}\right)$ than those on the floating tongue $\left(0.277 \mathrm{~km}^{2}\right)$.

SGLs on the grounded ice do not exhibit a large difference in depth characteristics compared with those on the floating tongue (Fig. 9). SGLs on the grounded ice are generally only slightly deeper, with a mean depth of $0.99 \mathrm{~m}$, compared with $0.98 \mathrm{~m}$ on the floating ice. SGLs on the grounded ice also have a higher spread of depth values, with Std dev. of 0.86 $\mathrm{m}$ and $0.49 \mathrm{~m}$ for maximum and mean depth, compared with $0.72 \mathrm{~m}$ and $0.40 \mathrm{~m}$, respectively, on the floating ice.

\section{DISCUSSION}

\section{Intra- and interseasonal evolution of meltwater features on the floating tongue (2014-16)}

We observe interseasonal variations in all the lake-related statistics that we calculate; TLN, TLA, TLV and MLD (Fig. 3 and Fig. S1), but, as with previous studies of SGLs on grounded ice (Liang and others, 2012; Leeson and others, 2013), we observe no clear interseasonal relationship between our calculated SGL statistics and air temperature. Strong interseasonal variations linked to air temperature are especially unlikely at low-elevation sites such as this, close to the terminus, where the melt and surface conditions necessary for
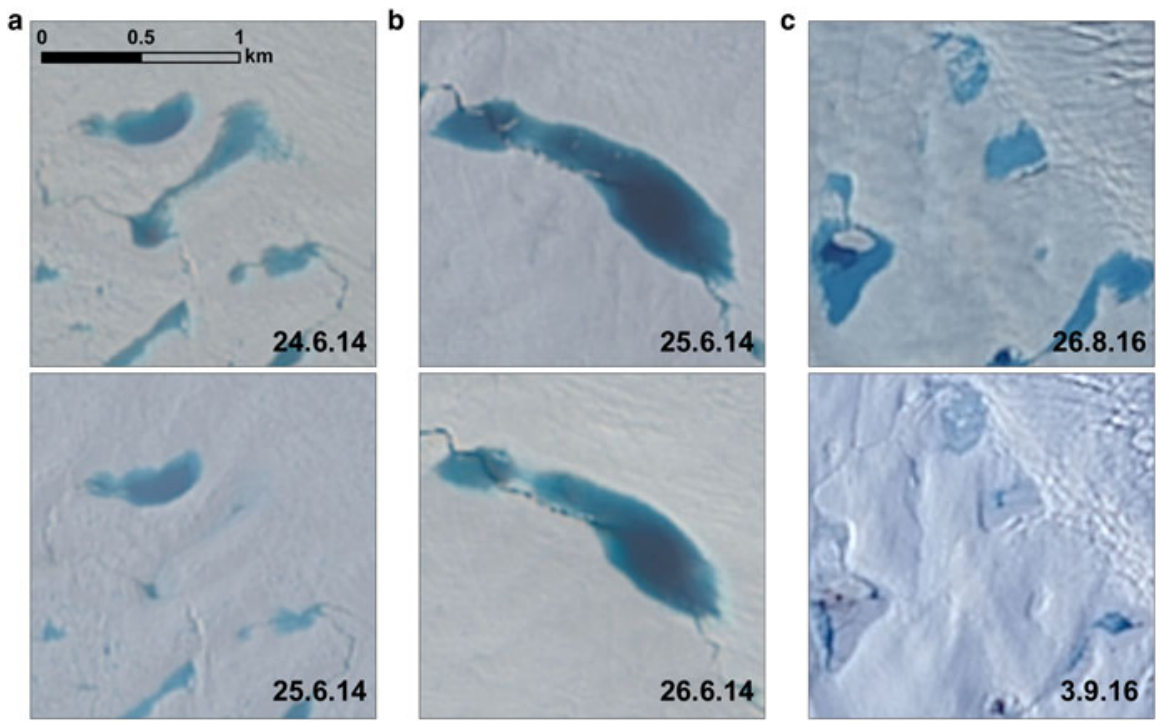

Fig. 6. Examples of lake drainage and burial/freeze-over events. Lake locations are indicated in Figure 1. (a) Lake A on 24 and 25 June 2014 , before and after the rapid lake drainage event is shown in Figure 7a. (b) Lake B on 25 and 26 June 2014, during the rapid lake drainage event, is shown in Figure 7b. (c) A group of lakes (C) that become buried by snow and ice between 26 August and 3 September 2016. 

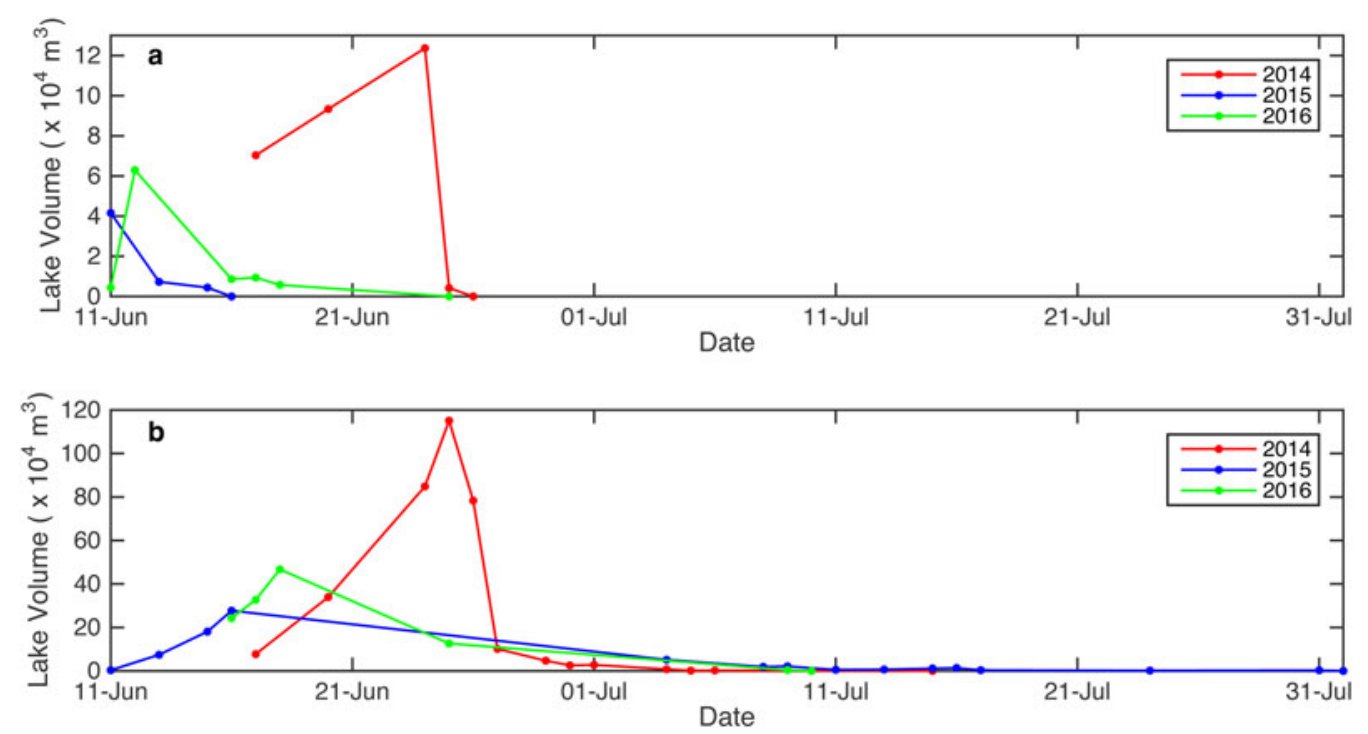

Fig. 7. Development and drainage of lakes (a) A, and (b) B, from 2014-16. In 2014, Lakes A and B drain 'rapidly', with Lake A losing $96 \%$ of its volume in one day and Lake B losing $30 \%$ of its volume 1 day, followed by a further $61 \%$ of its peak volume over the following day. Lakes A and B both drain 'slowly' in 2015 and 2016.

ponding are likely met in both warm and cold years (Liang and others, 2012), including all years in our study period. Further, it is likely that the lake basins fill to their maximum capacity in both warmer and cooler melt seasons, meaning that much of the extra meltwater produced in warmer years simply drains from the tongue, rather than increasing the volumes of SGLs.

The rapid development of SGLs once mean temperatures reach $0{ }^{\circ} \mathrm{C}$ in each melt season portrays a high sensitivity to small changes in surface air temperature beyond a critical temperature threshold (Bartholomew and others, 2010). The rapid growth in TLV (Fig. 3) and TLA (Fig. S1) is further facilitated by the positive feedback between surface melting and lake
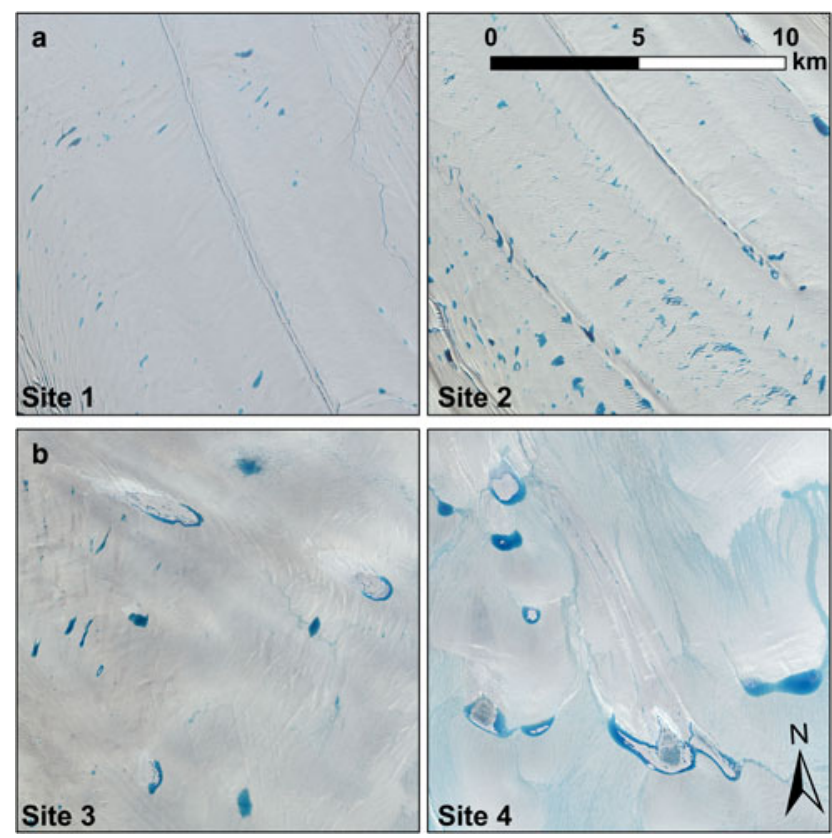

Fig. 8. A comparison of SGLs on the (a) floating tongue (Sites 1 and 2) and (b) grounded region (Sites 3 and 4) of Petermann Glacier in pansharpened OLI images. Sites 1-4 are located at increasingly up-glacier positions, as indicated in Figure 1, and the images were captured on 27 June 2014 for Site 1, and 30 June 2014 for Sites 2-4. growth associated with the low albedo of lake water compared with the surrounding ice/snow; a process which has been observed to enhance ablation $<135 \%$ on the GrIS (Tedesco and others, 2012). Finally, as could be expected, SGLs begin to develop later in the melt season than has been previously observed on warmer, lower latitude glaciers of the GrlS. For example, SGLs began to develop as early as May in the Paakitsoq region $\left(\sim 69^{\circ} \mathrm{N}\right)$ in 2001 (McMillan and others, 2007) and at Russell Glacier $\left(\sim 67^{\circ} \mathrm{N}\right)$ in $2007-09$ (Johansson and others, 2013).

From mid-late June until late June/early July, there is a decrease in TLN despite a continued increase in TLV (Fig. 3). The accompanying increase in MLD suggests that this occurs partly because multiple SGLs coalesce into fewer deeper, larger SGLs and partly because some lakes completely drain while others increase in volume.

There are a few possible explanations for the overall decline of TLN, TLV and TLA from mid-late July, which shows no clear relationship with temperature. First, the concurrent relatively stable nature of MLD suggests that many SGLs drain rapidly and completely, likely by hydrofracture (i.e. as slow/partial drainage would be associated with a decline in MLD). Though, notably, the stability of MLD alongside a decrease in TLN suggests that there is not a relationship between the depth of a lake on the tongue and its tendency to rapidly drain. Second, the meltwater plume (Fig. 5) suggests the central river likely efficiently evacuates meltwater over the ice tongue front, thereby reducing TLV in the latter part of the melt season. For example, Bell and others (2017) showed that a similar river had an important role in exporting meltwater from the Nansen Ice Shelf, Antarctica.

The increased spatial coverage of SGLs closer to the grounding line in late June and early July (Fig. S2), while overall TLN, TLA and TLV decline, can partly also be explained by the shift in peak volume of meltwater runoff from closer to the terminus towards the grounding line over a similar period (Fig. 2). Additionally, it can be partly explained by the inflow of surface meltwater from the up-glacier grounded ice, as surface melting in higher-elevation areas likely only commences in the mid-late melt season once air temperatures 

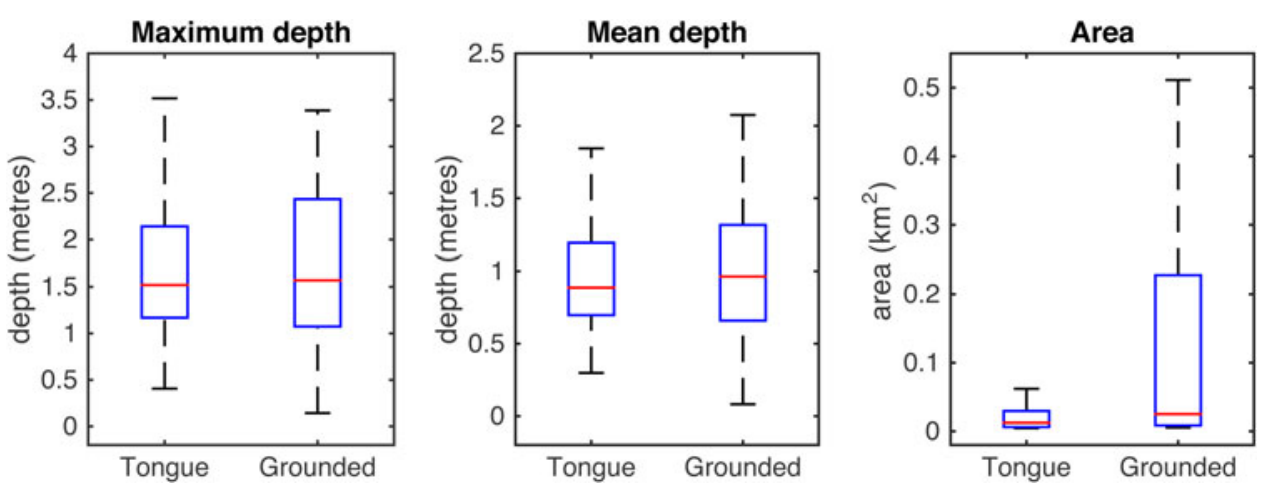

Fig. 9. Box plots of maximum depth, mean depth and area of SGLs at two sites on Petermann's floating tongue (1 and 2, Fig. 1) and two sites on the grounded ice ( 3 and 4, Fig. 1). On each box, the red mark is the median and the edges of the box are the 25th and 75th percentiles (q1 and $q 3$, respectively). The length of the whiskers (dashed lines) are equal to $q 3+1.5(q 3-q 1)$. The measurements were made using OLI images from 27 June 2014 (Site 1) and 30 June 2014 (Sites 2-4) that are shown in Figure 8.

are sufficiently high. Similar observations of meltwater from up-glacier areas flooding floating portions have been made on the Nivlisen (Kingslake and others, 2015) and Roi Baudouin ice shelves (Lenaerts and others, 2016). We, therefore, suggest that surface melting on Petermann's grounded ice forms an important contribution to the surface hydrology of its floating tongue.

\section{Individual lake development and drainage}

Our observations of rapid (i.e. $<48 \mathrm{~h}$ ) lake drainage on Petermann's floating tongue (Figs $6 \mathrm{a}$ and $\mathrm{b}$, and 7) suggest that SGLs likely drain vertically by hydrofracture, as previously discussed. The rapid drainage of Lakes A and B in 2014, but not 2015 and 2016 (Fig. 7) may be explained by the substantially higher peak lake volumes in $2014(\sim 3 \times$ that of 2015 , and $\sim 2 \times$ that of 2016 for Lake $A$, and $\sim 4 \times$ that of 2015 and $\sim \times 2$ that of 2016 for Lake B) (Weertman, 1973; van der Veen, 1998, 2007; Alley and others, 2005).

Slow drainage events (e.g. Lakes A and B in 2015 and 2016), and/or the freeze over/burial of some lakes at the end of the season (e.g. Fig. 6c), on Petermann's tongue suggest that the preconditions for hydrofracture (e.g. the presence of a fracture (Das and others, 2008) or sufficient lake volume (Alley and others, 2005; van der Veen, 2007; Arnold and others, 2014)) may not exist for some SGLs. Slow lake drainage events by surface overflow have been observed elsewhere on both grounded ice of the GrIS (e.g. Tedesco and others, 2013; Poinar and others, 2015) and floating ice of the AIS (e.g. Langley and others, 2016). And likewise, the freezeover and/or burial-by-snow of many SGLs is also common elsewhere in areas such as East Antarctica (e.g. Langley and others, 2016) and higher-elevation regions of the GrlS (e.g. Koenig and others, 2015; Poinar and others, 2015). It is unclear whether these lakes on Petermann freeze-through or remain as englacial features, but in any case, the existence of such storage features limits further meltwater contribution to surface streams and lakes. Latent heat release from any freezing may affect the energy balance of the upper layers of snow/firn/ice (e.g. Humphrey and others, 2012).

\section{Comparison of lakes on floating ice with those on grounded ice}

The lower mean and maximum areas of SGLs on the floating tongue, compared with those on the grounded ice (Fig. 9), can primarily be explained by the various processes that govern each set of lakes' formation. Meltwater on the tongue appears to pond in densely-spaced flow stripes, crevasses and surface undulations that form in response to ice flow, flexure and the ice crossing the grounding line, as previously observed on Antarctic ice shelves (e.g. McGrath and others, 2012; Banwell and others, 2014). This pattern of lake formation is particularly apparent on the floating ice close to the grounding line (Fig. 8a). Also, lake volumes on the tongue are relatively small because of the small catchment areas of each lake, due to the low gradient of the tongue. In contrast, meltwater on the grounded ice largely ponds in less-densely spaced, larger depressions (Fig. 8b) that likely reflect bedrock topography (Echelmeyer and others, 1991; Sergienko, 2013). Here, catchment areas are also larger, like those observed in other grounded regions of the GrIS (e.g. Banwell and others, 2014; Poinar and others, 2015).

\section{CONCLUSION}

Focusing on three melt seasons, 2014, 2015 and 2016, we present the first quantitative study of SGL characteristics on a floating ice tongue in Greenland. We take advantage of the narrower bands and higher acquisition rate of Landsat 8 OLI compared with its predecessor, Landsat 7 ETM+, which allows us to constrain spatial and temporal variations in surface hydrology on Petermann Glacier to a daily temporalresolution on occasions.

We show that SGLs form across Petermann's floating ice tongue during each melt season. In each year, SGLs develop in early-mid June as air temperatures begin to rise, and the total number of SGLs and their total volumes peak in late June/early July. Despite sustained high temperatures through July and August in each year, the total meltwater storage in SGLs falls during this time. We suggest that this may be due to both meltwater transportation across the tongue and into the ocean by a river, and due to lake drainage events on the tongue. However, we note that as the MLD stays relatively constant during this time, a large proportion of the lakes that drain must be doing so rapidly and completely, likely by hydrofracture. (NB. in this study we only actually observe two rapid lake drainage events.) Many other SGLs drain more slowly (either completely or partially) and the remainder do not drain at all, but instead become covered by snow/ice. Lakes on the tongue have a mean area $\sim 20 \%$ of those on the grounded ice and exhibit lower variability in maximum and 
mean depth, differences which are due to the contrasting formation processes of lakes in each environment.

Based on previous studies of SGLs on Antarctic ice shelves, the presence of SGLs on Petermann's floating tongue may be indicative of its vulnerability to instability and potential collapse (e.g. Scambos and others, 2000, 2003; Banwell and others, 2013). We find lakes to cover $<2.8 \%$ of the total surface area of Petermann's tongue, compared with the $5.3 \%$ of Larsen B's area that was covered prior to its collapse in 2002 (Banwell and others, 2014). Predicted future rises in air temperature (Kirtman and others, 2013) could enable a higher density of lakes, with larger volumes, to develop from earlier in the season, possibly leading to increased ice tongue instability. However, the decline of SGLs through July and August in each year studied, despite sustained high temperatures during those months, suggests that evacuation of meltwater from the tongue (e.g. by a river cf. Bell and others, 2017) may limit the total volumes of meltwater storage on Petermann's floating tongue, thereby mitigating the risk of instability and break-up.

\section{SUPPLEMENTARY MATERIAL}

The supplementary material for this article can be found at https://doi.org/10.1017/aog.2018.9

\section{ACKNOWLEDGEMENTS}

GJM acknowledges support from a NASA Earth and Space Science Fellowship (NNX15AN44H), and AFB acknowledges support from a Leverhulme/Newton Trust Early Career Fellowship. This work was also supported by U.S. National Science Foundation grant PLR-1443126. Peter Langen is thanked for supplying DMI temperature and runoff data. Neil Arnold and Andrew Williamson are thanked for their early support with implementing the lake area and depth algorithms. We are also very grateful to the Editor, Dirk van As and two reviewers (Amber Leeson and anonymous) whose helpful comments enabled us to considerably improve the paper.

\section{REFERENCES}

Alley R, Dupont T, Parizek B and Anandakrishnan S (2005) Access of surface meltwater to beds of sub-freezing glaciers: preliminary insights. Ann. Glaciol., 40, 8-14 (doi: 10.3189/ 172756405781813483)

Arnold NS, Banwell AF and Willis IC (2014) High-resolution modelling of the seasonal evolution of surface water storage on the Greenland ice sheet. Cryosphere., 8, 1149-1160 (doi: 10.5194/ tc-8-1149-2014)

Bamber JL, Siegert MJ, Griggs JA, Marshall SJ and Spada G (2013) Paleofluvial mega-canyon beneath the central Greenland ice sheet. Science, 341(6149), 997-999 (doi: 10.1126/science. 1239794)

Banwell AF and MacAyeal DR (2015) Ice-shelf fracture due to viscoelastic flexure stress induced by fill/drain cycles of supraglacial lakes. Antarct. Sci., 27, 587-597 (doi: 10.1017/ S0954102015000292)

Banwell AF and 5 others (2012) Calibration and validation of a high resolution surface mass balance model for Paakitsoq, West Greenland. J. Glaciol., 58(212), 1047-1062 (doi: 10.3189/ 2012JoG12J034)

Banwell AF, MacAyeal DR and Sergienko OV (2013) Breakup of the Larsen $B$ ice shelf triggered by chain reaction drainage of supraglacial lakes. Geophys. Res. Lett., 40, 5872-5876 (doi: 10.1002/2013GL057694)

Banwell AF and 5 others (2014) Supraglacial lakes on the Larsen B ice shelf, Antarctica, and at Paakitsoq, West Greenland: a comparative study. Ann. Glaciol., 55, 1-8 (doi: 10.3189/ 2014AoG66A049)

Bartholomew I and 5 others (2010) Seasonal evolution of subglacial drainage and acceleration in a Greenland outlet. Nat. Geosci., 3, 408-411 (doi: 10.1038/ngeo863)

Bell RE and 9 others (2017) Antarctic ice shelf potentially stabilized by export of meltwater in surface river. Nature, 544, 344-348 (doi: 10.1038/nature22048)

Bevan S L and 9 others (2017) Centuries of intense surface melt on Larsen C ice shelf. Cryosphere, 11(6), 2743-2753 (doi: 10.5194/tc-11-2743-2017)

Box JE and Ski K (2007) Remote sounding of Greenland supraglacial melt lakes: implications for subglacial hydraulics. J. Glaciol., 53 (181), 257-265 (doi: 10.3189/172756507782202883)

Das SB and 6 others (2008) Fracture propagation to the base of the Greenland ice sheet during supraglacial lake drainage. Science, 320(5877), 778-781 (doi: 10.1126/science.1153360)

DeConto RM and Pollard D (2016) Contribution of Antarctica to past and future sea-level rise. Nature, 531(7596), 591-597 (doi: 10.1038/nature17145)

De Rydt J, Gudmundsson GH, Rott H and Bamber JL (2015) Modeling the instantaneous response of glaciers after the collapse of the Larsen B ice shelf. Geophys. Res. Lett., 42, 53555363 (doi: 10.1002/2015GL064355)

Dupont TK and Alley RB (2005) Assessment of the importance of iceshelf buttressing to ice-sheet flow. Geophys. Res. Lett., 32(4), L04503 (doi: 0.1029/2004GL022024)

Echelmeyer K, Clarke TS and Harrison WD (1991) Surficial glaciology of Jakobshavn Isbrae, West Greenland: part 1. Surface morphology. J. Glaciol., 37(127), 368-382 (doi: 10.3198/ 1991JoG37-127-368-382)

Gilbert R and Domack EW (2003) Sedimentary record of disintegrating ice shelves in a warming climate, Antarctic Peninsula. Geochem. Geophys. Geosyst., 4(4), 1038 (doi: 10.1029/2002GC000441)

Glasser NF and Scambos TA (2008) A structural glaciological analysis of the 2002 Larsen B ice-shelf collapse. J. Glaciol., 55 (191), 400-410 (doi: 10.3189/002214309788816597)

Hogg AE, Shepherd A, Gourmelen N and Engdahl M (2016) Grounding line migration from 1991 to 2011 on Petermann Glacier, North-West Greenland. J. Glaciol., 62(236), 11041114 (doi: 10.1017/jog.2016.83)

Humphrey NF, Harper JT and Pfeffer WT (2012) Thermal tracking of meltwater retention in Greenland's accumulation area. J. Geophys. Res., 117(F01010) (doi: 10.1029/2011JF002083)

Johansson AM, Jansson P and Brown IA (2013) Spatial and temporal variations in lakes on the Greenland ice sheet. J. Hydrol., 476, 314-320 (doi: 10.1016/j.jhydrol.2012.10.045)

Kingslake J, Ng F and Sole A (2015) Modelling channelized surface drainage of supraglacial lakes. J. Glaciol., 61(225), 185-199 (doi: 10.3189/2015JoG14J158)

Kingslake J, Ely JC, Das I and Bell RE (2017) Widespread movement of meltwater onto and across Antarctic ice shelves. Nature, $\mathbf{5 4 4}$ (349), 349-352 (doi: doi:10.1038/nature22049)

Kirtman B and 16 others (2013) Near-term climate change: projections and predictability. In Strocker TF and 9 others eds. Climate change 2013: the physical science basis. Contribution of working group 1 to the fifth assess. Report of the Int. Panel on Clim. Cha. Cambridge Univ. Press, Cambridge, UK, 953-1028

Koenig LS and 11 others (2015) Wintertime storage of water in buried supraglacial lakes across the Greenland ice sheet. Cryosphere, 9, 1333-1342 (doi: 10.5194/tc-9-1333-2015)

LaBarbera CH and MacAyeal DR (2011) Traveling supraglacial lakes on George VI ice shelf, Antarctica. Geophys. Res. Lett., 38(24), L24501 (doi: 10.1029/2011GL049970)

Langen PL and 13 others (2015) Quantifying energy and mass fluxes controlling Godthåbsfjord freshwater input in a 5-km simulation 
(1991-2012). J. Clim., 28, 3694-3713 (doi: 10.1175/JCLI-D-1400271.1)

Langen PL, Fausto RS, Vandecrux B, Mottram RH and Box JE (2017) Liquid water flow and retention on the Greenland ice sheet in the regional climate model HIRHAM5: local and large-scale impacts. Front. Earth Sci., 4(110), 1-18 (doi: 10.3389/feart.2016.00110)

Langley ES, Leeson AA, Stokes CR and Jamieson SSR (2016) Seasonal evolution of supraglacial lakes on an East Antarctic outlet glacier. Geophys. Res. Lett., 43(16), 8563-8571 (doi: 10.1002/2016GL069511)

Le Brocq AM and 8 others (2013) Evidence from ice shelves for channelized meltwater flow beneath the Antarctic ice sheet. Nature Geo., 6, 945-948 (doi: 10.1038/NGEO1977)

Leeson AA and 7 others (2013) A comparison of supraglacial lake observations derived from MODIS imagery at the western margin of the Greenland ice sheet. J. Glaciol., 59(218), 1179_ 1188 (doi: 10.3189/2013JoG13J064)

Lenaerts JTM and 12 others (2016) Meltwater produced by windalbedo interaction stored in an East Antarctic ice shelf. Nature Clim. Cha., 7, 58-62 (doi: 10.1038/NCLIMATE3180)

Liang Y-L and 7 others (2012) A decadal investigation of supraglacial lakes in West Greenland using a fully automatic detection and tracking algorithm. Remote Sens. Environ., 123, 127-138 (doi: 10.1016/j.rse.2012.03.020)

MacAyeal DR and Sergienko OV (2013) The flexural dynamics of melting ice shelves. Ann. Glaciol., 54(63), 1-10 (doi: 10.3189/ 2013AoG63A256)

McGrath D and 5 others (2012) Basal crevasses on the Larsen C ice shelf, Antarctica: implications for meltwater ponding and hydrofracture. Geophys. Res. Lett., 39(16), L16504 (doi: 10.1029/ 2012GL052413)

McMillan M, Nienow P, Shepherd A, Benham T and Sole A (2007) Seasonal evolution of supra-glacial lakes on the Greenland ice sheet. Earth Planet. Sci Lett., 262(3), 484-492

Moon T, Joughin I, Smith B and Howat I (2012) 21st-Century evolution of Greenland outlet glacier velcoities. Science, 336, 576578 (doi: 10.3189/2014JoG13J135).

Mouginot J and 7 others (2015) Fast retreat of Zachariæ Isstrøm, Northeast Greenland. Science, 350(6266), 1357-1361 (doi: 10.1126/science.aac7111)

Münchow A, Padman L and Fricker HA (2014) Interannual changes of the floating ice shelf of Petermann Gletscher, North Greenland, from 2000 to 2012. J. Glaciol., 60(221), 489-499 (doi: 10.3189/2014JoG13J135)

Nick FM and 8 others (2012) The response of Petermann Glacier, Greenland, to large calving events, and its future stability in the context of atmospheric and oceanic warming. J. Glaciol., 58 (208), 229-239 (doi: 10.3189/2012JoG11J242)

Poinar K and 5 others (2015) Limits to future expansion of surface-meltenhanced ice flow into the interior of Western Greenland. Geophys. Res. Lett., 42, 1800-1807 (doi: 10.1002/2015GL063192)

Pope A and 6 others (2016) Estimating supraglacial lake depth in West Greenland using Landsat 8 and comparison with other multispectral methods. Cryosphere, 10(1), 15-27 (doi: 10.5194/tc-10-15-2016)

Rignot E (1998) Hinge-line migration of Petermann Gletscher, North Greenland, detected using satellite-radar interferometry. J. Glaciol., 44(148), 469-476 (doi: 10.1017/S0022143000001994)

Rignot E and 5 others (2004) Accelerated ice discharge from the Antarctic Peninsula following the collapse of Larsen B ice shelf. Geophys. Res. Lett., (31), L18401 (doi: 10.1029/2004GL020697)

Rott H, Müller F, Nagler T and Floricioiu D (2011) The imbalance of glaciers after disintegration of Larsen-B ice shelf, Antarctic
Peninsula. Cryosphere, 5(1), 125-134 (doi: 10.5194/tc-5-1252011)

Scambos TA, Hulbe C, Fahnestock M and Bohlander J (2000) The link between climate warming and break-up of ice shelves in the Antarctic Peninsula. J. Glaciol., 46(154), 516-530 (doi: 10.3189/172756500781833043)

Scambos TA, Hulbe C and Fahnestock M (2003) Climate-induced ice shelf disintegration in the Antarctic Peninsula. In Domack EW, Burnett A, Leventer A, Conley P, Kirby M and Bindschadler R eds. Antarctic Peninsula climate variability: a historical and paleoenvironmental perspective. American Geophysical Union, Washington, DC, 79-92

Scambos TA, Bohlander JA, Shuman CA and Skvarca P (2004) Glacier acceleration and thinning after ice shelf collapse in the Larsen B embayment, Antarctica. Geophys. Res. Lett., 31(18), L18402 (doi: 10.1029/2004GL020670)

Selmes N, Murray T and James TD (2011) Fast draining lakes on the Greenland ice sheet. Geophys. Res. Lett., 38(15), L15501 (doi: 10.1029/2011GL047872)

Sergienko O (2013) Glaciological twins: basally controlled subglacial and supraglacial lakes. J. Glaciol., 59(213), 3-8 (doi: 10.3189/2013JoG12J040)

Sneed WA and Hamilton GS (2007) Evolution of melt pond volume on the surface of the Greenland ice sheet. Geophys. Res. Lett., 34 (3), L03501 (doi: 10.1029/2006GL028697)

Tedesco M and 7 others (2012) Measurement and modeling of ablation of the bottom of supraglacial lakes in Western Greenland. Geophys. Res. Lett., 39(2), L02502 (doi: 10.1029/ 2011GL049882)

Tedesco M and 5 others (2013) Ice dynamic response to two modes of surface lake drainage on the Greenland ice sheet. Environ. Res. Lett., 8(3), 034007 (doi: 10.1088/1748-9326/8/3/034007)

Tedesco M and 7 others (2014) Greenland Ice Sheet [in Arctic Report Card (2014)], http://www.arctic.noaa.gov/Report-Card

Tedesco M and 10 others (2015) Greenland Ice Sheet [in Arctic Report Card (2015)], http://www.arctic.noaa.gov/Report-Card

Tedesco M and 10 others (2016) Greenland Ice Sheet [in Arctic Report Card (2016)], http://www.arctic.noaa.gov/Report-Card

Thomsen HH, Thorningm L and Braithwaite RJ (1988) Glacierhydrological conditions on the Inland Ice north-east of Jacobshavn/Illulisat, West Greenland. Rapp. Grønl. Geol. Unders., 138 (Copenhagen, Denmark)

van As D and 6 others (2016) Placing Greenland ice sheet ablation measurements in a multi-decadal context. Geol. Surv. Den. Greenl. Bull., 35, 71-74

van der Veen CJ (1998) Fracture mechanics approach to penetration of bottom crevasses on glaciers. Cold Reg. Sci. Tech., 27(3), 213223 (doi: 10.1016/S0165-232X(98)00006-8)

van der Veen C J (2007) Fracture propagation as means of rapidly transferring surface meltwater to the base of glaciers. Geophys. Res. Lett., 34(1), L01501 (doi: 10.1029/2006GL028385)

Walker RT and 5 others (2013) Ice-shelf tidal flexure and subglacial pressure variations. Earth \& Planet. Sci. Lett., 361, 422-428 (doi: 10.1016/j.epsl.2012.11.008)

Weertman J (1973) Can a water-filled crevasse reach the bottom surface of a glacier? IAHS Publ., 95, 139-145

Williamson AG, Willis IC, Arnold NS and Banwell AF (2018) Controls on rapid supraglacial lake drainage in West Greenland: an Exploratory Data Analysis approach. J. Glaciol. (doi: 10.1017/jog.2018.8)

Wuite J and 7 others (2015) Evolution of surface velocities and ice discharge of Larsen B outlet glaciers from 1995 to 2013. Cryosphere, 9, 957-968 (doi: 10.5194/tc-9-957-2015) 